\title{
PENGARUH PENDIDIKAN TERHADAP PENDAPATAN DOMESTIK REGIONAL BRUTO DI INDONESIA
}

\author{
M. Nur Rianto Al Arif \\ Universitas Indonesia \\ m.nur01@ui.ac.id
}

\begin{abstract}
.
The aim of this research is to analyze the influence of education on gross domestic regional product at 33 provinces in Indonesia. The analysis method that used in this research is multiple regressions with six independent variables such as literacy rate, years of school, enrolment rate 1, enrolment rate 2, enrolment rate 3, and population. The result shown that years of school and population had an influence on gross domestic regional product in Indonesia, and literacy rate, enrolment rate 1, enrolment rate 2, and enrolment rate 3 didn't have an influence of gross domestic regional product. From this result we can conclude that overall education had an impact on growth in Indonesia.So, the government should make a good education program to increase the growth of Indonesian economy.
\end{abstract}

Keywords: Education, Gross Domestic Regional Product, Multiple Regression

\begin{abstract}
Abstrak.
Tujuan dari penelitian ini ialah untuk menganalisis pengaruh pendidikan terhadap pendapat domestik regional bruto pada 33 propinsi di Indonesia. Metode analisis yang dipergunakan dalam penelitian ini ialah regresi berganda dengan menggunakan enam variabel bebas yaitu angka melek huruf, jumlah tahun sekolah, tingkat partisipasi sekolah 1, tingkat partisipasi sekolah 2, tingkat partisipasi sekolah 3, dan populasi. Hasil yang ada menunjukkan bahwa jumlah tahun sekolah dan populasi memiliki pengaruh terhadap pendapatan domestik regional bruto. Sedangkan empat variabel bebas lainnya tidak memiliki pengaruh terhadap pendapatan domestic regional bruto. Dari hasil ini dapat disimpulkan bahwa secara umum pendidikan memiliki dampak terhadap pertumbuhan di Indonesia. Oleh karenanya pemerintah sebaiknya membuat suatu program pendidikan yang baik untuk meningkatkan pertumbuhan ekonomi Indonesia.
\end{abstract}

Kata Kunci: pendidikan, pendapatan domestik regional bruto, regresi berganda.

Diterima: 20 Januari 2014; Direvisi: 20 Maret 2014; Disetujui: 25 Maret 2014 


\section{PENDAHULUAN}

Pendidikan merupakan bagian dari investasi yang akan dapat memberikan keuntungan. Dengan melibatkan unsur manusia di dalam analisis investasi, maka muncul gagasan baik dalam mengembangkan pemikiran untuk menjadikan pendidikan dan pelatihan secara terpisah bilamana dibandingkan dengan teori ekonomi konvensional. Semakin kaya khasanah pemahaman terhadap unsur manusia, melalui pentingnya kualitas manusia baik secara langsung maupun secara tidak langsung telah dapat membantu para perencana di bidang pendidikan di dalam menyusun perencanaan pendidikan, termasuk ke dalam lingkup ini pengaturan sumber pembiayaan pendidikan yang relatif langka.

Pendekatan dalam mempelajari input dan output dari pendidikan melibatkan dua sisi, yaitu sisi pertama adalah memanfaatkan analisis makroekonomi yaitu dengan membawa bidang ekonomi ke dalam perencanaan pembangunan. Sisi kedua ialah dengan memanfaatkan analisis mikroekonomi. Sehingga dengan demikian, mata kuliah mikroekonomi dan makroekonomi merupakan mata kuliah prasyarat yang sudah diambil oleh mahasiswa yang berminat untuk mendalami ekonomi pendidikan. Hal itu akan dapat membantu dalam memahami pendidikan ini sebagai suatu proses dalam pembentukan modal manusia.

Investasi modal manusia memiliki beberapa perbedaan dengan investasi pada modal fisik. Hal ini perlu dibahas, agar pembaca dapat memahami mengapa investasi modal manusia tersebut penting. Terdapat beberapa perbedaan antara investasi modal manusia dengan investasi pada modal fisik, hal ini dapat terlihat pada Tabel 1. Penjelasan pada Tabel 1 meringkaskan berbagai aspek penting yang membedakan antara modal fisik dengan modal manusia, dimana pendidikan merupakan salah satu strategi peningkatan nilai stok manusia. Perbedaan pertama ialah terkait dengan biaya yang mungkin timbul dari penyediaan modal manusia dan modal fisik. Modal fisik akan menimbulkan suatu biaya ekonomi dalam proses penyediaan modal tersebut, namun modal fisik tersebut akan terus menyusut sepanjang waktu sehingga harus dilakukan pembelian kembali apabila nilai ekonomisnya telah habis. Sedangkan biaya yang timbul dari modal manusia, biaya ekonomi akan timbul dari proses penyediaan modal manusia baik apakah melalui pendidikan ataupun pelatihan. 
Selain itu akan timbul pula biaya sosial dalam penyediaan modal manusia tersebut. Misalkan apabila seorang individu memutuskan untuk melanjutkan ke jenjang pendidikan lebih tinggi, maka ia harus mengeluarkan biaya ekonomi berupa biaya pendidikan yang harus dibayarkan, namun selain itu ada biaya sosial yang harus dia tanggung yaitu berupa biaya sosial berupa waktu ataupun semakin berkurangnya kebebasan bersosialisasi karena individu tersebut harus fokus kepada studinya.

Tabel 1. Kriteria Perbedaan Investasi Manusia dan Fisik

\begin{tabular}{|c|c|c|}
\hline Kriteria & Manusia & Fisik \\
\hline Biaya & $\begin{array}{l}\text { Biaya sosial } \\
\text { Biaya ekonomi }\end{array}$ & $\begin{array}{l}\text { Biaya ekonomi } \\
\text { penyusutan }\end{array}$ \\
\hline Manfaat & $\begin{array}{l}\text { Manfaat sosial } \\
\text { Manfaat ekonomis }\end{array}$ & $\begin{array}{l}\text { Manfaat ekonomis melalui } \\
\text { tingkat pengembalian }\end{array}$ \\
\hline Waktu & $\begin{array}{l}\text { Tidak langsung dan semakin } \\
\text { berguna secara non linear }\end{array}$ & $\begin{array}{l}\text { Langsung dan semakin } \\
\text { berkurang kegunaannya }\end{array}$ \\
\hline Sifat & Kegiatan konsumsi dan investasi & Kegiatan investasi \\
\hline $\begin{array}{l}\text { Sumber } \\
\text { pembiayaan }\end{array}$ & $\begin{array}{l}\text { Individu, rumah tangga dan } \\
\text { pemerintah }\end{array}$ & Kalangan yang merencanakan \\
\hline
\end{tabular}
Sumber: Elfindri (2011)

Perbedaan kedua ialah terkait dengan manfaat yang akan didapat dari penyediaan modal tersebut. Dalam penyediaan modal fisik, manfaat ekonomis akan didapat melalui tingkat pengembalian yang harus lebih besar dibandingkan dengan biaya ekonomis yang dikeluarkan. Sedangkan pada penyediaan modal manusia selain manfaat ekonomis terdapat pula manfaat sosial.

Sebagai contoh, dengan melanjutkan pendidikan ke jenjang lebih tinggi maka individu tersebut memiliki manfaat ekonomis berupa kesempatan untuk mendapatkan kenaikan gaji ataupun penyesuaian kenaikan pangkat sehingga pendapatannya dapat lebih meningkat. Serta terdapat pula manfaat sosial yang berguna apabila ilmu tersebut mampu diaplikasikan baik di tempat ia bekerja ataupun kepada masyarakat sekitar.

Perbedaan berikutnya ialah terkait dengan waktu, pada penyediaan modal fisik waktunya bersifat langsung dapat dirasakan manfaatnya pada saat modal fisik tersebut tersedia dan seiring dengan perubahan waktu maka akan semakin berkurang kegunaannya. Misalkan perusahaan membeli mesin, maka manfaatnya akan dirasakan secara langsung pada saat itu juga dengan mampu menaikkan kapasitas produksi, namun seiring waktu akan semakin berkurang kegunaannya karena teknologinya sudah tertinggal. Sedangkan pada modal manusia manfaat 
tersebut tidak mampu dirasakan manfaatnya saat itu juga (tidak langsung), dan semakin berguna secara non-linear.

Hasil pendidikan akan dirasakan manfaatnya dilihat dari peningkatan produktivitasnya dalam bekerja. Selanjutnya apabila dilihat dari sifatnya, modal fisik merupakan kegiatan yang sifatnya investasi karena pengeluaran yang dikeluarkan dari memperoleh modal fisik tersebut diperbandingkan dengan tingkat pengembaliannya. Sedangkan pada modal manusia selain bersifat investasi berupa peningkatan nilai intrinsik seseorang sebagai akibat pendidikan, dapat pula bersifat konsumsi karena ada biaya yang harus dikeluarkan dalam memperoleh modal manusia tersebut.

Semakin banyak seseorang memperoleh pendidikan, seharusnya semakin banyak pula memperoleh berbagai jenis kompetensi. Kompetensi yang mesti diperoleh oleh setiap orang yang mengenyam pendidikan sesuai dengan taksonomi Bloom (Encyclopedia of Educational Research: 1992 dalam Elfindri, 2011: 83), yakni, kompetensi keilmuan (ranah afektif) yang diperlukan otak (knowledge), kompetensi keterampilan kerja (skilled) (masuk ranah psikomotorik), dan kompetensi emosional dan soft skills. Pintar secara akademik saja tidak cukup, jika tidak diimbangi dengan kompetensi yang lain. Untuk menciptakan manusia yang holistik ialah harus mampu mencetak generasi yang memiliki berbagai kompetensi tersebut disesuaikan dengan bakat dan kemampuan masing-masing anak.

Terdapat dua alasan mendasar untuk berharap menemukan beberapa hubungan antara pendidikan dan pertumbuhan ekonomi. Pertama, secara umum pada berbagai tingkatan terdapat kenaikan standar hidup pada milenium terakhir ini dan semenjak tahun 1800-an karena faktor pendidikan. Pada berbagai pengamatan terlihat bahwa terdapat hubungan antara kemajuan pengetahuan dalam kaitannya dengan pendidikan dalam memfasilitasi perkembangan dari ilmu pengetahuan. Tetapi beberapa orang yang memiliki keterbatasan pendidikan seringkali menemukan kesulitan untuk memfungsikannya dalam masyarakat yang lebih maju. Pendidikan dibutuhkan untuk orang-orang agar mendapatkan manfaat dari kemajuan pengetahuan sehingga dapat berkontribusi positif terhadap mereka. Kedua, pada tingkatan yang lebih spesifik, suatu cakupan dari kajian ekonometrika mengindikasikan bahwa pendapatan individu tergantung pada tingkatan pendidikan yang mereka tempuh. Orang yang berpendidikan akan mampu menghasilkan lebih banyak dibandingkan dengan mereka yang tidak 
berpendidikan. Proses dari pendidikan dapat dianalisis sebagai suatu keputusan investasi dari individu.

Hubungan antara pendidikan dan kinerja perekonomian dengan menggunakan data historis yang memiliki beberapa keterbatasan data, penelitian yang dilakukan oleh Maddison (1991) yang memperlihatkan PDB perkapita pada tahun 1913 dengan tingkat masuk sekolah dari pendidikan dasar pada tahun 1882 di negara Inggris, Prancis, Jerman, Spanyol, Italia, Jepang, Brasil dan Korea Selatan. Berdasarkan kajian yang dilakukan terlihat bahwa tingginya tingkat PDB per kapita dari negara yang diteliti memiliki hubungan dengan tingginya tingkat masuk sekolah dari pendidikan dasar pada 30 tahun terakhir. Karena kedua faktor tersebut baik tingkat pendidikan dan tingkat PDB perkapita pada suatu periode tertentu memiliki hubungan yang dekat antara tingkat pendidikan tahun sebelumnya dan PDB perkapita tahun sesudahnya.

Terdapat beberapa kajian terkait hal tersebut di atas. Salah satu contoh adalah kajian yang dilakukan oleh Matthews dkk (1982) yang memperlihatkan bahwa diantara tahun 1856 dan 1973 kenaikan jenjang pendidikan berkontribusi sebesar 0,3 persen per tahun terhadap pertumbuhan output di Inggris (dengan rata-rata pertumbuhan sebesar 1,9 persen per tahun). Dougherty dan Jorgenson (1997) melakukan kajian yang memperlihatkan kontribusi peningkatan kualitas tenaga kerja terhadap masukan tenaga kerja di negara-negara G7. Dengan menggunakan kerangka perhitungan pertumbuhan memperlihatkan bahwa kontribusi mereka terhadap pertumbuhan ekonomi secara keseluruhan dapat ditemukan dengan mengalikan terhadap bagian dari tenaga kerja. Hal yang perlu dicatat ialah kualitas tenaga kerja merupakan variabel yang lebih luas dibandingkan pendidikan.

Kekurangan dari model ini ialah adanya suatu fakta bahwa pertumbuhan dalam faktor produktivitas total merupakan eksogen. Jika tingkat pertumbuhan dari faktor produktivitas total itu sendiri tergantung pada tingkat dari perubahan dalam pencapaian pendidikan, maka perhitungan pertumbuhan akan dipahami sebagai suatu hal yang benar bahwa pendidikan berkontribusi terhadap pertumbuhan ekonomi di suatu negara.

Terdapat beberapa cara yang dilakukan agar faktor produktivitas total menjadi sesuatu yang bersifat endogen. Mereka cenderung berangkat dari fungsi produksi 
dengan berbagai tipe tenaga kerja atas berbagai tingkatan pendidikan yang berbeda. Lucas (1988), sebagai contoh, mengasumsikan bahwa, sebagai tambahan dari persediaan modal fisik, ada suatu variabel metafisik yang disebut dengan modal manusia, $h$. Tingkat rata-rata dari modal manusia dalam perekonomian ditentukan oleh tingkat dari faktor produktivitas total.

$$
y=A h_{a}^{\gamma} f(k, u h)
$$

Pada model pertumbuhan endogen ini, modal manusia memainkan peran. Pertama, jika $f$ merupakan tingkat pengembalian konstan, maka, modal manusia dan fisik meningkat dalam jumlah yang tetap. Tetapi jika $y>0$ maka secara keseluruhan akan terjadi tingkat pengembalian yang meningkat. Output meningkat lebih banyak dibandingkan dengan proporsi peningkatan dalam penawaran faktor produksi. Secara khusus peningkatan dari persediaan modal manusia seharusnya memiliki pengaruh terhadap tingkat pertumbuhan dari output. Tingkat pertumbuhan dari modal manusia dapat ditulis sebagai berikut:

$$
\frac{\grave{h}}{h}=\pi(1-u)
$$

Persamaan diatas untuk menunjukkan suatu perbedaan yang tajam dengan yang dilakukan oleh Mankiw, dkk. Mereka mengasumsikan bahwa pengembalian dari dua faktor produksi, modal manusia dan modal fisik, ialah lebih kecil dari satu. Implikasi yang terjadi ialah, meskipun persediaan modal manusia dan fisik meningkat tanpa ada batasan, secara rata-rata pertumbuhan output akan menurun secara asimtotik terhadap tingkatan yang diatur oleh pertumbuhan dari variabel eksogen, $A$. Sebaliknya, dalam model Lucas, output tergantung hanya pada faktor yang diproduksi dan disediakan, output dapat tumbuh tanpa batas.

Pada model ini dan sebelumnya, peningkatan dari pencapaian pendidikan (diasumsikan terkait dengan modal manusia) akan memicu peningkatan dari output. Model Lucas mengimplikasikan bahwa modal manusia dapat meningkat meskipun tanpa adanya peningkatan dari pencapaian pendidikan. Walaupun modal manusia dari individu dapat berkurang sepanjang waktu, maka terdapat suatu pengetahuan umum dan akumulasi modal manusia untuk menambahnya. Sehingga, meskipun pencapaian pendidikan telah berhenti meningkat, maka modal manusia dapat terus berlanjut meningkat dan keberlanjutan dari pertumbuhan dapat terjadi. 
Masih ada kesulitan untuk mendapatkan suatu penjelasan yang memuaskan dari seluruh kajian yang ada dalam melihat pengaruh pendidikan terhadap pertumbuhan ekonomi. Analisis mikroekonomi menyediakan estimasi dari pengaruh pendidikan terhadap pendapatan individu, dan peneliti cenderung lebih nyaman dengan kajian makroekonomi yang menyediakan estimasi dari tingkat pengembalian yang serupa dengan hasil temuan dalam kajian mikroekonomi, pada rentang $6-12$ persen. Karena hasil yang didapat menyarankan apakah pengembalian yang lebih tinggi atau lebih rendah dapat menyebabkan penurunan kredibilitas, maka mungkin terdapat suatu elemen bias seleksi pada temuan yang dipublikasikan tersebut.

Salah satu kesulitan yang terjadi dalam mengukur pengaruh pendidikan (yang diproksikan dengan tingkat pencapaian pendidikan atau lamanya menempuh pendidikan) dengan tingkat pertumbuhan ekonomi adalah permasalahan jeda waktu (time-lag). Karena pengaruh dari pendidikan tidak dapat dilihat secara langsung pengaruhnya di suatu tahun. Pengaruh dari pendidikan mungkin akan baru terasa setelah beberapa tahun setelah terjadi peningkatan dalam pencapaian pendidikan tersebut. Dalam kajian yang telah dilakukan di beberapa negara maju menunjukkan bahwa waktu yang memperlihatkan hubungan antara peningkatan pencapaian pendidikan dan pertumbuhan ekonomi membutuhkan waktu yang lama. Namun bukan berarti pendidikan tidak menjadi faktor penting dalam pertumbuhan ekonomi suatu negara. Karena pendidikan merupakan salah satu upaya dalam meningkatkan kapasitas modal manusia yang berguna bagi pembangunan ekonomi.

\section{METODE}

Data yang dipergunakan dalam penelitian ini ialah data pendapatan domestik regional bruto, tingkat melek huruf, rata-rata lama sekolah, angka partisipasi sekolah, dan jumlah penduduk dari 33 propinsi di Indonesia dengan menggunakan data yang berasal dari Badan Pusat Statistik. Teknik analisis yang dipergunakan dalam penelitian ini adalah teknik regresi berganda. Adapun persamaan matematis yang diajukan pada penelitian ini ialah:

$Y_{i}=\alpha+\beta_{1}$ Literacy $_{i}+\beta_{2}$ Years $_{i}+\beta_{3}$ Enrolment_1 $1_{i}+\beta_{4}$ Enrolment_2 $+\beta_{5}$ Enrolment_ $3_{i}+\beta_{6}$ Population $_{i}+\varepsilon$ 


$$
\begin{array}{ll}
\text { dimana } & =\text { pendapatan regional bruto } \\
\text { Literacy } & =\text { tingkat melek huruf } \\
\text { Years } & =\text { rata-rata lama sekolah } \\
\text { Enrolment_1 } & =\text { angka partisipasi sekolah usia } 7-12 \text { tahun } \\
\text { Enrolment_2 } & =\text { angka partisipasi sekolah usia } 13-15 \text { tahun } \\
\text { Enrolment_1 } & =\text { angka partisipasi sekolah usia } 16-18 \text { tahun } \\
\text { Population } & =\text { jumlah penduduk }
\end{array}
$$

Setelah dilakukan pengolahan regresi menggunakan regresi berganda, perlu dilihat apakah model tersebut baik ataukah jelek, atau dalam bahasa statistik perlu dilihat goodness of fit dari model tersebut. Untuk melihat goodness of fit dari model dengan melihat pada hasil $t$ statistik, $F$ statistik, koefisien determinasi $\left(R^{2}\right)$. (Sugiyono, 2007)

Pengujian t statistik adalah suatu prosedur dengan sampel yang digunakan untuk verifikasi kebenaran atau kesalahan dari hipotesis nol. Ide kunci di belakang uji signifikansi adalah suatu uji statistik dan distribusi sampel dari suatu statistik hipotesis nol. Keputusan menerima atau menolak $\mathrm{H}_{0}$ dibuat pada basis nilai uji statistik yang diperoleh dari data yang sudah ada. Di bawah asumsi normalitas variabel mengikuti distribusi statistik $t$ dengan derajat bebas $\mathrm{N}-\mathrm{k}$. Suatu statistik dikatakan signifikan secara statistik jika nilai uji statistik berada pada daerah kritis. Begitu pula sebaliknya apabila uji statistik dikatakan tidak signifikan. Dalam pengolahan uji statistik $t$ bertujuan untuk melihat seberapa besar pengaruh variabel independen terhadap variabel dependen secara individu.

$$
t=\left[\beta_{s}-\beta\right] / \operatorname{se}\left(\beta_{s}\right)
$$

Pengujian hipotesis nol dengan statistik $F$ sangat perlu untuk menguji apakah $\beta_{k}=$ 0 . Perhitungan statistik $F$ dari ANOVA dilakukan dengan membandingkan dengan nilai kritis $\mathrm{F}$ yang diperoleh dari tabel distribusi $\mathrm{F}$ pada tingkat signifikansi tertentu. Apabila hipotesis nol ditolak berarti variabel independen mempengaruhi variabel dependen. Dalam pengolahan empiris hal ini bertujuan untuk melihat pengaruh variabel independen secara bersama-sama terhadap variabel dependen. Koefisien 
determinasi atau $R^{2}$ merupakan ukuran goodness of fit yang menjelaskan apakah regresi linear sesuai dengan data observasi.

Koefisien determinasi adalah suatu ukuran yang menjelaskan besar variasi regressan akibat perubahan variabel regressor. Koefisien determinasi mengukur proporsi atau persentase dari total variasi regressan yang dijelaskan oleh model regresi. Jika $R^{2}=1$ artinya hubungan regressan dengan regressor sempurna, sebaliknya $R^{2}=0$ artinya tidak ada hubungan regressan dengan regressor. Dalam pengolahan empiris hal ini dilakukan untuk melihat seberapa besar model tersebut diterangkan oleh variabel yang ada.

\section{HASIL DAN PEMBAHASAN}

Berdasarkan hasil pengolahan yang dilakukan dapat terlihat bahwa pengaruh antara angka melek huruf, jumlah tahun belajar, angka partisipasi sekolah dan populasi terhadap pendapatan domestik regional bruto dapat ditulis sebagai berikut:

$Y=20.1615+4.32618$ Literacy +66.34562 Years +0.7472 Enroll_1

$\begin{array}{lllll}\mathrm{t} & 2.6401 & 0.2189 & 2.9917 & 0.16079\end{array}$

+ 3.5227 Enroll_2 + 5.2476 Enroll_3 + 1.0773 Population

t $\quad 0.47469 \quad 1.3054 \quad 7.5107$

F 12.49119

Adj $R^{2} \quad 0.683002$

Berdasarkan hasil pengolahan regresi di atas menunjukkan bahwa hanya ada dua variabel bebas yang memiliki pengaruh terhadap pembentukan pendapatan domestik regional bruto pada 33 propinsi di Indonesia yaitu variabel rata-rata lama sekolah (jumlah tahun sekolah) dan populasi. Sedangkan angka melek huruf, dan tingkat partisipasi sekolah di usia $7-12$ tahun, $13-15$ tahun dan $16-18$ tahun tidak memiliki pengaruh terhadap pembentukan pendapatan domestik regional bruto di Indonesia.

Hasil yang didapat menunjukkan bahwa terdapat pengaruh antara jumlah tahun bersekolah dengan pendapatan domestik regional bruto. Tanda positif menunjukkan bahwa apabila penduduk di suatu propinsi semakin tinggi tingkat pendidikannya (hal ini ditunjukkan dengan semakin lama tahun sekolahnya), maka akan semakin tinggi pendapatan domestik regional brutonya. 
Nilai koefisien sebesar 66.34562 menunjukkan bahwa apabila terjadi kenaikan rata-rata tahun sekolah akan mampu menaikkan PDRB sebesar 66.34 triliun.

Variabel populasi (jumlah penduduk) turut pula sebagai variabel yang mempengaruhi pembentukan pendapatan domestik regional bruto di suatu propinsi. Tanda positif menunjukkan bahwa apabila terjadi kenaikan populasi di suatu propinsi, maka akan mampu menaikkan pendapatan domestik regional bruto di propinsi tersebut. Nilai koefisien yang ada menunjukkan apabila terjadi kenaikan populasi sebesar 1000 orang akan mampu menaikkan PDRB sebesar 1,0773 triliun.

Variabel bebas lain seperti angka melek huruf, tingkat partisipasi sekolah berdasarkan usia menunjukkan hasil yang tidak berpengaruh. Hasil ini dapat disebabkan oleh pengaruh variabel ini mungkin belum terasa dampaknya dalam waktu dekat, namun mungkin akan dapat berpengaruh apabila telah terjadi jeda waktu yang cukup lama.

Hasil penelitian ini menunjukkan bahwa secara umum, pendidikan memiliki pengaruh terhadap pendapatan domestik regional bruto pada 33 propinsi di Indonesia. Berdasarkan penelitian ini memberikan rekomendasi kepada para pengambil kebijakan terutama pengambil kebijakan di tingkat propinsi maupun Kabupaten/Kota untuk memberikan perhatian yang lebih pada peningkatan kualitas pendidikan di daerah. Karena semakin tinggi kualitas sumber daya manusia yang ditunjukkan dengan tingkat pendidikan yang semakin tinggi, maka perekonomian di daerah tersebut akan mampu tumbuh lebih baik.

Matthews dkk (1982) yang memperlihatkan bahwa diantara tahun 1856 dan 1973 kenaikan jenjang pendidikan berkontribusi sebesar 0,3 persen per tahun terhadap pertumbuhan output di Inggris (dengan rata-rata pertumbuhan sebesar 1,9 persen per tahun). Dougherty dan Jorgenson (1997) melakukan kajian yang memperlihatkan kontribusi peningkatan kualitas tenaga kerja terhadap masukan tenaga kerja di negara-negara G7. Dengan menggunakan kerangka perhitungan pertumbuhan memperlihatkan bahwa kontribusi mereka terhadap pertumbuhan ekonomi secara keseluruhan dapat ditemukan dengan mengalikan terhadap bagian dari tenaga kerja. Hal yang perlu dicatat ialah kualitas tenaga kerja merupakan variabel yang lebih luas dibandingkan pendidikan. 
Kekurangan dari model ini ialah adanya suatu fakta bahwa pertumbuhan dalam faktor produktivitas total merupakan eksogen. Jika tingkat pertumbuhan dari faktor produktivitas total itu sendiri tergantung pada tingkat dari perubahan dalam pencapaian pendidikan, maka perhitungan pertumbuhan akan dipahami sebagai suatu hal yang benar bahwa pendidikan berkontribusi terhadap pertumbuhan ekonomi di suatu negara.

Pendidikan merupakan bagian dari investasi yang akan dapat memberikan keuntungan. Dengan melibatkan unsur manusia di dalam analisis investasi, maka muncul gagasan baik dalam mengembangkan pemikiran untuk menjadikan pendidikan dan pelatihan secara terpisah bilamana dibandingkan dengan teori ekonomi konvensional. Melalui pendidikan, diharapkan mampu menghasilkan output sumber daya manusia yang berkualitas yang merupakan salah satu modal utama dalam suatu proses pembangunan ekonomi. Dengan pendidikan, diharapkan investasi modal manusia mampu memberikan keuntungan dalam peningkatan nilai intrinsik pada sumber daya manusia. Faktor penting dalam pengembangan sumber daya manusia terutama dalam kaitannya dengan mutu tenaga kerja adalah melalui sistem pendidikan dan latihan. Bagi daerah yang baru berkembang, penekanan perlu dilakukan melalui perbaikan angka melek huruf. Demikian pula latihan dan pembentukan keterampilan lebih penting dari penyediaan pendidikan tinggi. Program penyediaan keterampilan hendaknya ditujukan untuk sektor informal baik di kota maupun di desa, selain peningkatan keterampilan di sektor industri dan sektor tersier.

Salah satu kesulitan yang terjadi dalam mengukur pengaruh pendidikan (yang diproksikan dengan tingkat pencapaian pendidikan atau lamanya menempuh pendidikan) dengan tingkat pertumbuhan ekonomi adalah permasalahan jeda waktu (time-lag). Karena pengaruh dari pendidikan tidak dapat dilihat secara langsung pengaruhnya di suatu tahun. Pengaruh dari pendidikan mungkin akan baru terasa setelah beberapa tahun setelah terjadi peningkatan dalam pencapaian pendidikan tersebut. Dalam kajian yang telah dilakukan di beberapa negara maju menunjukkan bahwa waktu yang memperlihatkan hubungan antara peningkatan pencapaian pendidikan dan pertumbuhan ekonomi membutuhkan waktu yang lama. Namun bukan berarti pendidikan tidak menjadi faktor penting dalam pertumbuhan ekonomi suatu negara. Karena pendidikan merupakan salah satu upaya dalam 
meningkatkan kapasitas modal manusia yang berguna bagi pembangunan ekonomi.

Restrukturisasi yang cepat dari sifat produksi dan teknologi industri yang sekarang memerlukan suatu sistem pendidikan, pengembangan keterampilan dan mobilitas tenaga kerja yang fleksibel. Sistem pendidikan hendaknya fleksibel dan responsive terhadap perubahan-perubahan dan hendaknya meliputi aspek "know how" dan "know why" dari teknologi tersebut.

Untuk mendapatkan sumber daya manusia yang berkualitas melalui pendidikan, perlu disusun suatu indikator pendidikan. Indikator pendidikan dapat diungkapkan melalui dua pendekatan penyusunan indikator, pertama adalah indikator makroekonomi dan kedua dalah indikator mikroekonomi. Pada indikator makro yang lebih banyak mendapatkan penekanan ialah dari aspek pembiayaan pendidikan, rasio guru dengan murid, rasio kelas dengan murid, rasio buku di perpustakaan dengan murid, rasio tenaga administrasi dengan murid.

Keseluruhan indikator tersebut merefleksikan besarnya input pendidikan dalam kaitannya dengan proses pendidikan itu sendiri. Kemudian di lain pihak muncul beberapa indikator yang dapat juga untuk menilai kinerja pendidikan yang diukur untuk menilai sejauh mana kelangsungan pendidikan pada suatu lingkup daerah tertentu. Maka dengan demikian tingkat masuk sekolah (enrollment rate), tingkat ulangan, tingkat drop out, tingkat kelangsungan pendidikan berdasarkan jenjang pendidikan, dan sebagainya merupakan indikator output dari pendidikan. Sedangkan dari aspek kriteria mikro, dapat digunakan rata-rata pengeluaran untuk pendidikan rumah tangga per bulan sebagai indikator masukan (input), dan persentase individu yang mampu masuk ke suatu jenjang pendidikan sebagai indikator keluaran (output).

Serta dimasukkan pula kriteria individu, dengan indikator masukan pendidikannya menggunakan rata-rata jam belajar per hari. Kemudian indikator keluaran dari individu tersebut ialah indeks prestasi kumulatif yang mampu dicapai, serta gaji pertama yang dia peroleh setelah lulus pendidikan.

Pada Tabel 2 berikut dapat terlihat jelas berbagai kriteria dalam mengindikasikan pendidikan termasuk masukan, proses, dan keluaran. Indikator masukan dan indikator keluaran merupakan indikator yang relatif mudah diukur sedangkan 
indikator proses atau indikator sistem sulit untuk diukur, namun indikator ini menjadi bagian penting dalam keberhasilan pendidikan.

Tabel 2. Indikator Pendidikan

\begin{tabular}{|c|c|c|c|}
\hline Kriteria & Masukan & Proses & Keluaran \\
\hline Makro & $\begin{array}{l}\text { Persentase GNP } \\
\text { untuk pendidikan; } \\
\text { Rasio guru-murid; } \\
\text { Rasio buku-murid; } \\
\text { Gedung per murid }\end{array}$ & $\begin{array}{l}\text { Sistem pendidikan; } \\
\text { Undang-undang }\end{array}$ & $\begin{array}{l}\text { Tingkat drop out; } \\
\text { Repetitive rate; } \\
\text { Persentase } \\
\text { melanjutkan sekolah; } \\
\text { Partisipasi kasar } \\
\text { tenaga kerja; } \\
\text { Nilai Akhir Studi }\end{array}$ \\
\hline $\begin{array}{l}\text { Mikro } \\
\text { Rumah tangga }\end{array}$ & $\begin{array}{l}\text { Rata-rata pengeluaran } \\
\text { rumah tangga untuk } \\
\text { pendidikan per bulan }\end{array}$ & $\begin{array}{l}\text { Perhatian keluarga; } \\
\text { Lingkungan }\end{array}$ & $\begin{array}{l}\text { Persentase masuk ke } \\
\text { SD, SMP, SMA, } \\
\text { akademi, Perguruan } \\
\text { tinggi }\end{array}$ \\
\hline Individu & $\begin{array}{l}\text { Rata-rata jam belajar } \\
\text { per hari }\end{array}$ & $\begin{array}{l}\text { Fisik dan lingkungan } \\
\text { serta intelejensia }\end{array}$ & 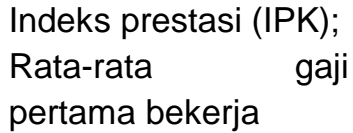 \\
\hline
\end{tabular}

Sumber: Elfindri (2011: 22)

\section{SIMPULAN}

Berdasarkan hasil penelitian yang dilakukan menunjukkan bahwa dari enam variabel bebas yang ada, ternyata hanya dua variabel yang memengaruhi pendapatan domestik regional bruto yaitu hanya rata-rata lama sekolah dan populasi. Hasil ini menunjukkan bahwa semakin tinggi populasi di suatu propinsi dan semakin lama penduduk di propinsi tersebut bersekolah, maka pendapatan regional brutonya pun akan semakin tinggi. Hasil yang ada turut pula menunjukkan bahwa tingkat melek huruf dan partisipasi sekolah berdasarkan usia tidak memiliki pengaruh terhadap pendapatan domestik regional bruto.

Penelitian ini telah membuktikan bahwa semakin lama penduduk di suatu propinsi tersebut bersekolah, dimana hal ini menunjukkan bahwa semakin tinggi tingkat pendidikan di propinsi tersebut akan berpengaruh terhadap pertumbuhan ekonomi di propinsi tersebut yang diproksikan dengan pendapatan regional bruto. Namun tingkat melek huruf yang tinggi ternyata tidak memiliki pengaruh, hal ini menunjukkan bahwa mungkin saja tingkat melek huruf tinggi namun kemampuan dasar membaca tersebut tidak memiliki dampak pada peningkatan produktivitas penduduk di propinsi tersebut. Jika dilihat secara rata-rata dari 33 propinsi tingkat melek huruf di Indonesia sebesar 
93,35\%. Hasil penelitian ini memberikan rekomendasi kepada pemerintah agar senantiasa secara terus menerus melakukan pembangunan di sektor pendidikan, karena pendidikan akan berkontribusi pada peningkatan pertumbuhan ekonomi di suatu propinsi. Semakin tinggi tingkat pendidikan penduduk di suatu Negara, maka akan semakin baik pula proses pembangunan yang berlangsung di daerah tersebut.

\section{PUSTAKA ACUAN}

Al Arif, M. Nur Rianto. 2014. Buku Materi Pokok Ekonomi Pendidikan. Jakarta: UT Press

Checchi, Danielle. 2005. The Economics of Education. Cambridge: Cambridge University Press

Dustman, Christian, et.al (ed). 2008. The Economics of Education and Training. Heidelberg: Springer

Elfindri. 2011. Pendidikan Sebagai Barang Ekonomi. Bandung: Lubuk Agung

Gujarati, Damodar dan Dawn C. Porter. 2009. Basic Econometrics $5^{\text {th }}$ edition. McGraw Hill: New York

Johnes, Geraint \& Jill Johnes (ed). 2004. International Handbook on The Economics of Education. Northampton: Edward Elgar Publishing

Schmidt, Stephen J. 2005. Econometrics. McGraw Hill: New York

Sekaran, Uma. 2003. Research Methods for Business: A Skill Building Approach. New York: John Wiley \& Sons

Sugiyono. 2007. Metode Penelitian Bisnis. Bandung : CV. Alfabeta

Woolridge, Jeffrey. M. 2002. Econometrics Analysis of Cross Section and Panel Data. The MIT Press; Cambridge Massachusetts 